\title{
Sustainable Economic Development in Thailand
}

\author{
Anawat Bunnag
}

\begin{abstract}
Thinkers and academics around the word are in search of alternative approaches to the Western economic model that signifies the capitalist economy which supports a short-term maximizing profit and optimizing its shareholder's value. In 2006, after the UN Secretary General, Kofi Annan presented a Human Development Life-Time Achievement Award to His Majesty King Bhumibhol Adulyadej of Thailand, and the publication of UNDP Thailand Human Development Report about the Philosophy of Sufficiency Economy in 2007, his work has become worldwide recognized as an efficient means towards sustainable development with a focus on human development. The philosophy of Sufficiency Economy is basically a means to achieve happiness at the individual, community and country levels because the Sufficiency Economy Approach is applicable to the micro and macro levels. All the principles are much related to human development process toward right living, therefore right interaction and relation with other beings on this planet including natural resources. From this basis, the Philosophy of Sufficiency Economy provides a practical tool to cultivate necessary conditions and to alter human well-being through happiness development process.
\end{abstract}

Index Terms-Sustainable economy, sufficiency economy, thai economy, thailand, king bhumiphol, king of thailand.

\section{INTRODUCTION}

Thinkers and Academics around the world are in search of alternative approaches to the Western economic model that signifies the capitalist economy which supports a short-term maximizing profit and optimizing its shareholder's value. They contend that capitalism with its Western business practice could not lead to corporate sustainability [1]-[3]. It was not until 1997 that the Philosophy of Sufficiency Economy (PhilSE) has become publicly acknowledged when Thailand had to devalue its currency and obtained loans from the IMF. His Majesty King Bhumibol Adulyadej mentioned a remedial process in his address on the eve of his birthday anniversary on December 4, 1997 that

"Recently, so many projects have been implemented, so many factories have been built, and that it was thought Thailand would become a little tiger and then a big tiger. People were crazy about becoming a tiger.

Being a tiger is not important. The important thing for us is to have a sufficient economy.

A sufficient economy means to have enough to support ourselves. A careful step backward must be taken. A return to less sophisticated methods must be made with less advanced instruments.

However, it is a step backward in order to make further progress." [4]

Manuscript received October 10, 2012; revised December 24, 2012.

Anawat Bunnag is with the Philosophy and Religion, Assumption University, Bangkok, Thailand (e-mail: anawatbunnag@hotmail.com).
The Philosophy of Sufficiency Economy has originated from a life-long accumulation of knowledge and experiences of His Majesty the King during his life-long devotion to provide a mean toward community development which has been evident for more than 60 years. He has always concerned with sustainable development so that human can live in balance with nature and other beings.

Later, in his royal speech on December 4, 1998, His Majesty explained more on the Philosophy of Sufficiency Economy that:

"This 'sufficiency' means a 'sufficiency economy.' It is satisfactory if each individual has enough to live on, but it is even better if the entire country has enough to live on.

We in Thailand used to be sufficient. Now, it is free to be insufficient. Therefore, it is a policy to adopt a sufficiency economy so that everyone has enough to live on.

Sufficiency means to lead a reasonably comfortable life, without excess or overindulgence in luxury but having enough." [4].

Moreover, His Majesty also explained that Sufficiency Economy differs from the English term and idea of "self-sufficiency" that.

"Self-sufficiency means producing enough for one's own need, without having to borrow anything from others, or as they say, standing on one's own feet. But the Sufficiency Economy concept is much broader than that.

Sufficiency is moderation. If one is moderate in one's desires, one will take less advantage of others. If all nations hold this concept, without being extreme or insatiable in one's desires, the world will be a happier place.

Being moderate does not mean to be too strictly frugal: luxurious items are permissible, but one should not take advantage of others in the fulfillment of one's desires. Moderation, in other words, living within one's means, should dictate all actions. Act in moderation, speak in moderation that is, be moderate in all activities.

Therefore, sufficiency means moderation and reasonableness." [4]

In 2006, after the UN Secretary General, Kofi Annan presented a Human Development Life-Time Achievement Award to the King, and the publication of UNDP Thailand Human Development Report in 2007, his work has become worldwide recognized as an efficient mean towards sustainable development with a focus on human development [5]-[6].

\section{Sustainable ECONOMIC DEVELOPMENT}

The ultimate goal of development in today's world has shifted from that of economic growth to improvement of human well-being because the majority of the world's populations still suffer from lacking of basic necessities in life 
including food, shelter, education and healthcare. Though poverty is one of the causes of low quality of life, improving human well-being does not involve merely monetary value. The ability of people to make their own choices is also vital. The Philosophy of Sufficiency Economy (PhilSE) treats this problem at a very fundamental level by focusing on the idea that individuals and families should be able to rely on themselves as the most important part of the development. In order to achieve self-reliance condition, the PhilSE offers three basic principles which are moderation, reasonableness and self-immunity [5]-[7].

Moderation represents the concept of people living their lives on the middle path contrary to those on the extreme ends. They live their lives without overindulgence because they are reasonable. They are aware of the consequence of overindulgence, living along the extreme line and being unreasonable. It implies that they can develop self-immunity from sudden change, internal or external, because of their reasonableness. In addition, knowledge and morality are also essential in order to complete the Sufficiency Economy's requirement for success.

\section{UNITED NATION RECOGNITION}

The United Nation Development Program (UNDP) has stated in its investigation into the Philosophy of Sufficiency Economy (PhilSE) that the heart of the development in the context of the PhilSE corresponds to the UNDP agenda on development, which is human well-being. Focusing on the people to live up to their own potential and lead their fullest lives possible in freedom and with dignity [8]. It is this freedom of self-reliance that the PhilSE can introduce which could free Thai people from the trap of materialism in which citizens of capitalist societies are normally caught. It is the most enjoyable freedom that is attainable by the practice of Philosophy of Sufficiency Economy.

\section{CAPITALIST ECONOMY IN OUR CONTEMPORARY DEMOCRATIC SOCIETY}

Today, democracy is the sacred word of almost all of the leaders on this planet. Democracy is identified with the system of deregulated free-market economy, a ruthless opposition to communism, a right to intervened, militarily and others, in many sovereign nations and their internal affairs---to call all this democracy should be viewed as an incredible success. To manage to make the free market be considered as an evident condition of democracy and to have democracy viewed as inseparable with the free market economy is an astounding accomplishment. It suffices to say that in reality the main system of rule and regulation in our society today, is precisely the economy.

In short, in our $21^{\text {st }}$ century society, it must be accompanied by a tag that says 'it is a democratic society'. However, the absence of reality, the democratic symbol as subjectivity enslaved to monetary circulation, and the important of universal pleasure seeking can guide any society toward a disastrous end. Since the substitutability of everything with money plays a vital part in democratic/capitalist society, it follows that the society is incapable of organizing any disciplines or any order of everything. Laws, social rules and regulations are useless, subjective and double-standard. Sooner or later this manner of existence, grounded in the indiscipline of pleasure-seeking behavior and its related form of government, the so-called representative democracy, will bring about a visible manifestation of their empty essence.

The symbol of today's world is democracy and youth is a character of that symbol, representing the absence of discipline on the aspect of time. If money, youth and pleasure-seeking behavior equals to today's democracy, then the imperative ingredient to democratic society is its disciplinary and unselfish attitude.

Democracy of today can be considered as the reign of limitless desire of individuals in mass society. Democratic government "is bad when it is allowed to be corrupted by democratic society, which wants for everyone to be equal and for all differences to be respected" [9]. For some, democracy does not refer to a corrupt form of government but it does, even worse, represent a crisis of civilization that troubles the society and privatizes the affairs of the State. Democracy triumphed in the Middle East, we were told, despite protests by citizen who believes that democracy consists in the government of the people by the people and so cannot be imposed on a country by the force of arms. Imposing democracy to another country does not solely mean pouring into the country the beneficial effects of a constitutional State, free election, universal suffrage and freedom of the press. The accompanied negative effects also simply include social disorder.

It is because democracy does not intrinsically emerge as the government of the people, by the people, but it was the disorder of desires from protesters eager for satisfaction that democracy must be introduced from outside by the army of superpowers. Democracy signifies the irresistible growth of demands that put pressure on governments, lead to a decline in authority and cause individuals and groups to become more disobedient to discipline and sacrifices required for the common good.

However, the campaign to promote the worldwide rise of democracy has revealed its paradox. On one hand, democracy is opposed to arbitrary government, which is government without limits, be it tyranny, dictatorship or totalitarianism.

On the other hand, an effective democratic government must be able to control the democratic society comprised of democratic citizen enjoying their democratic life. The intensity of democratic life is similar to the 'anarchic' principle that affirms the power of the people, the power to contest and persistently protesting authority of the State, to undermine the principles of good government, to disrespect public authorities and to disobey any expert advices.

The solution to the excess of political energy that democracy brought about is to reverse the direction of that energy towards the quest for individual satisfaction. Promoting a vitality of private life would unavoidably lead to increase in demands and desire which would make citizens inattentive to the public good because they are too busy with their personal concerns. Democracy has finally become the regime that cultivates 'egotistical individuals' who, at the same time, are recognized as 'greedy consumers' of the 
free-trade economy.

This means that Western democratic society represents "nothing but the reign of the narcissistic consumer varying his or her electoral choices and his or her intimate pleasures alike" [9].

In the past, politics was an art of living together and a search for the common good and the essence of this art was a clear distinction between the domain of common affairs and that of private life of domestic interests. In the present, politics is ruined by postmodern democracy in which society are governed by the law of consumerist individuality and the firmly fixed identical identity between democratic man and individual consumer. They become two faces of the same coin and that was how democracy was reduced from state affair into society affair [9].

It follows that the root of all evil is identified as democratic individualism. It was the unequal society that evolves the youngster into consumers overwhelmed by the notion of equality which are synonyms to democracy as well as "plunging of all of existence into the sphere of consumption" [9].

The question yesterday was about equality and social inequality but the question today is only how to transmit knowledge of virtues and traditions that has to be saved from the self-destructive tendency being born in today Western "democratic" society.

\section{SUFFICIENCY ECONOMY AS THE BASIS FOR THE DEVELOPMENT OF DEMOCRACY IN THAILAND}

In order to be free from the disastrous capitalist society under the illusions of Western democracy, we have to firstly, change the attitude and the misconception that if we are to become true democracy, we must adopt the practice of free-market trade and the mindset of mass consumerism including all the characteristic of individualism living in the capitalist economy.

Secondly, in order to survive the effect of globalization, we should reinvent our own version of democracy which is rooted in our culture, traditions and sovereignty. The result of this reinvention would be the version of democracy that coexists with the economic practice that focuses more on the importance of human well-being on the basis of local wisdom and morality called 'the Philosophy of Sufficiency Economy'.

His Majesty King Bhumibol Adulyadej, in 1999, has explained the meaning of Sufficiency Economy in details that,

"Sufficiency Economy is the Philosophy that addresses the way of living and practice of the public in general from the family unit and the community, to the national level, in development and management of the country towards the middle path especially in developing the economy to keep up with the world in the era of globalization.

The word "Sufficiency" means moderation and reasonableness including the need to have self-immunity to be ready against any internal and external shocks. In addition, the application of theories in planning and implementation requires great care and good judgment at every stage.

At the same time, all members of the nation, especially officials, intellectuals, and business people, need to develop their commitment to the importance of knowledge, ethical, integrity, and honesty to conduct their lives with perseverance, toleration, Sati and Pañña, and precaution so that the country has the strength and balance to respond to rapid and widespread changes materialistically, socially, environmentally, and culturally from the outside world." [10].

In sum, the Philosophy of Sufficiency Economy (PhilSE) consists of three components and two underlying conditions. The three components are moderation, reasonableness and a self-immunity system meaning the ability to sustain internal and external change. Moreover, the underlying conditions necessary for Sufficiency Economy are knowledge and morality.

From recent case studies of large business in Thailand that survive the 1997economic crisis, they all share common characters which can be identified with the PhilSE [7] i.e. moderation and reasonableness. They all conduct their business in moderation by focusing on long-term improvement instead of short-term maximizing benefits. They are reasonable in their business practice by being accountable for all stakeholders not only their shareholders. They have self-immunity to sudden change by valuing human resources and thus, able to maintain their specific knowledge inside their organization which is essential for their competitiveness. Moreover, they all cultivate innovativeness within organization to be able to progress in their field which is consistent to the PhilSE in acquiring knowledge

It suffices to say that the philosophy of Sufficiency Economy is acknowledged by many recent studies as an alternative approach to corporate sustainability.

\section{SUFFICIENCY Business PRACTICES}

There are empirical evidences from studies of both Thai and Western business enterprises that there are certain common practices among business entities that can help sustain their business during economic difficulties. The following practices are those common conducts among successful business entities which can also be identified as the Sufficiency Economy practices. [7]

1) Adopt a long-term perspective for decision-making in management level. Do not focus on short-term maximizing profit but emphasize on long-term effects.

2) Value and develop human resources as an essential investment. Do not lay off employees to cut cost.

3) Be honest and concern with the society, the environment as well as contribute to the welfare of the community. That is ready to, prepared for and responsible to a wide range of stakeholders including the environment and the society.

4) Nurture innovation throughout the organization in both products and manufacturing process which is often the result of promoting cross-functional teamwork.

5) Optimize the use of raw materials and resources.

6) Adopt local wisdom and try to develop inexpensive but effective manufacturing technology.

7) Careful investment by gradually expand the business when the firm is ready to grow not because of temporary market demand. 
8) Minimize risk by diversify products, expand markets and adjust investment portfolios.

9) Share knowledge to develop the market to benefit consumers. Synergizing with direct competitors and other firms in similar business could radically improve the industry.

10) Conduct business with ethic, perseverance and diligence.

The Philosophy of Sufficiency Economy aims to achieve major goals of balanced living, security, sustainability and resilience, all of which are basic elements of happiness. Hence the philSE is basically a means to achieve happiness at the individual, community and country levels because the Sufficiency Economy Approach is applicable to the micro and macro levels. All the principles in the PhilSE are much related to human development process toward right living, therefore it emphasizes on right interaction in relation with other beings on this planet including natural resources. From this basis, it suffices to say that the PhiSE provides a practical tool to cultivate necessary conditions in order to alter human well-being through happiness development process.

\section{CONCLUSION}

I would claim that the Philosophy of Sufficiency Economy is suitable for economic development in Thailand because it focuses on human development, values knowledge, concentrates on morality and transcends all diversity into unity. For it starts from cultivating individual values of honesty (morality)together with the practice of middle way or moderate living, greed or desire for personal gain of luxury things is controlled (reasonableness). When greed is limited there are rooms for compassion and sympathy for other beings and the urge to share the excess wealth with society to help the disadvantage. Exploitation of nature could also be reduced if people are honest to themselves about what is really necessary for them in order to be happy in their daily life. Fewer natural resources will be consumed if we drive fewer cars, own fewer homes, and enjoy less monetary and material gains. At the end, all diversity of want and greed will be transcended to the unity of compassion and sharing of our world.

It is evidenced by today's climate change and natural disaster that Western economic model has promoted the zero-sum game between human and nature, which represents dualism, the I-thou viewpoint. If we-human take the profit they-the environment and other species- will lose. The more we make money from exploiting nature, the more global warming effects, draught and natural catastrophe we would encourage and encounter.

Sufficiency economy promotes the real win-win situation with its holistic worldview that is focusing on the practice of living in moderation and harmoniously with nature. It is an approach that could make us, the I--human, and the thou--nature and other creatures-- all win. Less industrial plants could save rivers and trees from industrial pollution and poisoning. Less whale hunting, less deep-sea fishing can save those species from extinction and keep the balance of the earth planet's biological food chain, which can also help saving our human race from natural disaster, food and natural resources scarcity and finally, total extinction of our own specie as well.

\section{REFERENCES}

[1] G. C. Avery, Leadership for sustainable Futures: Achieving Success in a Competitive world, UK: Edward Elgar, 2005.

[2] H. Mintzberg, Managers not MBAs: A Hard Look at the Soft Practice of Managing and Management Development, CA: Berrett-Kehler, 2004.

[3] D. Dunphy, "Corporate sustainability: Challenge to managerial orthodoxies," Journal of the Australia and New Zealand Academy of Management, vol. 9, no. 1, pp. 2-11, 2003.

[4] Government Public Relations Department, King Bhumibol Adulyadej: The Great King of Communication, Bangkok: Paper House Limited Partnership, pp.101-103, 2007.

[5] B. Supadhiloke, "Synergy of 'Gross National Happiness' and 'Sufficiency Economy' as an Imperative Paradigm for Communication and Sustainable Social Change," in Proc. International Conference Future Imperatives of Communication and Information for Development and Social Change, Bangkok, December 20-22, 2010.

[6] P. Mongsawad, "The Philosophy of the Sufficiency Economy: a Contribution to the Theory of Development," Asia-Pacific Development Journal, vol. 17, no. 1, pp.123-143, June 2010.

[7] S. Kantabutra. (2007). Development of the Sufficiency Economy Philosophy in the Thai Business Sector: Evidence, Future Research \& Policy Implications. [Online]. Available: http://www.sufficiencyeconomy.org/old/en/files/26.pdf.

[8] United Nations Development Programme (UNDP), Thailand Human Development Report 2007: Sufficiency Economy and Human Development, Bangkok: UNDP, 2007.

[9] J. Rancière, Hatred of Democracy, London: Verso, pp.4-27, 2007.

[10] National Economic and Social Advisory Council (NESAC), Formulation and Evaluation of Sufficiency Economy Indicators and the Economic and Social Report on the National Performance in the Direction of Sufficiency Economy, Bangkok: Ubon Rajthanee University, pp. 5, 2007.

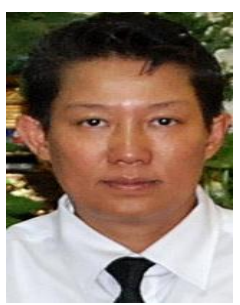

Anawat Bunnag was born and raised in Bangkok during 1970's-1980's, graduated with a Bachelor of Arts in Archaeology from Silapakorn University, Bangkok, Thailand, then went on to study for a Master of Arts in Liberal Studies from NYU, New York, USA during early1990's, later spent time in a program to earn a Master of Business Administration from UVIC, Canada in 1999

Anawat is currently in pursuit of the degree of Doctor of Philosophy in Philosophy, at Assumption University, Bangkok, Thailand with dissertation title "Carl Schmitt's Concept of Sovereignty and Its Implications for Thai Democracy". Graduation is expected in Dec, 2012 at the latest. 